\title{
ANALISIS ORIENTASI PASAR, MODAL SOSIAL DAN INOVASI PRODUK TERHADAP KINERJA PEMASARAN PEDAGANG DI PUSAT GROSIR SOLO
}

\author{
Reny Dwi Astuti, Bambang Mursito, Rochmi Widayanti \\ Fakultas Ekonomi Universitas Islam Batik Surakarta \\ renydwia27@gmail.com
}

\begin{abstract}
This research is a test of the influence of market orientation, social capital and product innovation on marketing performance at Pusat Grosir Solo. The population in this study is traders in Pusat Grosir Solo, the sample of the research amounted to 100 people, sampling techniques using accidental sampling, which is done by giving a questionnaire to be filled out by traders at Pusat Grosir Solo. The data analysis method used in this study is descriptive statistical analysis and regression analysis. Descriptive statistical analysis is the interpretation of data obtained in the study and the results of data processing that has been carried out by giving explanations and explanations. Regression analysis includes validity and reliability test, classic assumption test, multiple regression analysis, determination test, $F$ test and $t$ test. The results of the F test show that market orientation, social capital, and product innovation concurrent influence on the marketing performance at the Pusat Grosir Solo. Based on the results of partial hypothesis testing market orientation has a positive and significant effect on marketing performance at the Pusat Grosir Solo. Social capital has a positive and significant effect on marketing performance at the Pusat Grosir Solo. Product innovation has a positive and significant effect on marketing performance at the Pusat Grosir Solo. The results of the coefficient of determination, the results of the calculation of multiple linear regressione analysis can be seen that the adjusted amount of $R^{2}$ obtained is 0.651 or 65.1\%. This shows that market orientation, social capital and product innovation has an influence on the marketing performance of traders at Pusat Grosir Solo by 65.1\%.
\end{abstract}

Keyword: Market Orientation, Social Capital, Product Innovation, Marketing Perfomance

\section{PENDAHULUAN}

Di dalam perekonomian modern seperti sekarang ini, keadaan sudah berubah, banyaknya persaingan dalam dunia bisnis merupakan hal yang tidak dapat dihindari. Pada dasarnya tujuan perusahaan mendirikan suatu usaha untuk mendapatkan keuntungan maksimal. Oleh karena itu perusahaan dituntut untuk selalu berinovasi dan mampu memahami keinginan pasar serta menyusun strategi perusahaan yang efektif. Strategi perusahaan diarahkan untuk menghasilkan kinerja, baik kinerja keuangan maupun kinerja pemasaran (Sarjita, 2017). Faktor yang mempengaruhi kinerja pemasaran yaitu orientasi pasar. Menurut Ningsih (2016) Perusahaan yang berorientasi pada pasar merupakan perusahaan yang menjadikan pelanggan sebagai kiblat bagi perusahaan untuk menjalankan bisnisnya, agar dapat secara terus menerus berorientasi pada pelanggan, selain kepada pelanggan perusahaan juga harus berorientasi pada pesaing (competitor orientation). Kedua orientasi tersebut dapat terlaksana dengan baik jika perusahaan selalu melakukan koordinasi antar fungsional dengan baik. Orientasi pasar merupakan sesuatu yang sangat penting untuk perusahaan sejalan dengan meningkatnya persaingan global dan kebutuhan pelanggan yang selalu meningkat dan berubah-ubah dimana perusahaan menyadari mereka harus dekat dengan pasarnya. 
Faktor kedua yang mempengaruhi kinerja pemasaran adalah modal sosial. Menurut Sugiyanto dan Marka (2017) Modal sosial diartikan salah satu bentuk relasi yang ideal dalam kegiatan ekonomi di Indonesia. Pemasaran membutuhkan bekerjanya instrumen-instrumen manajemen yang berwajah sosial dan dalam kaitan ini modal sosial menjadi sangat relevan sebagai salah satu instrument strategis yang menghasilkan kinerja pemasaran. Ide sentral dari modal sosial merupakan merupakan asset yang bernilai. Modal sosial juga menekankan perlunya kemandirian dalam mengatasi masalah sosial dan ekonomi. Modal sosial bisa memberikan keunggulan bersaing bagi organisasi melalui, pengkombinasian, pertukaran dan penciptaan modal intelektual (Warmana dan Widnyana, 2018). Terbentuknya manajemen dan struktur organisasi formal pada usaha menengah mempresentasikan modal sosial yang baik. Modal sosial merupakan mediasi yang memperkuat hubungan antara orientasi pasar dengan kinerja pemasaran (Khoirrini dan Kartika, 2014).

Faktor ketiga yang mempengaruhi kinerja pemasaran adalah inovasi produk. Perusahaan harus berusaha mempergunakan sumber daya yang dimilikinya untuk berinovasi dan meningkatkan kinerja layanan yang memuaskan pelanggan. Inovasi merupakan mekanisme perusahaan untuk beradaptasi dengan lingkungan yang dinamis, sehingga perusahaan dituntut mampu menciptakan ide baru, penilaian baru, dan menawarkan produk yang inovatif serta peningkatan kinerja layanan yang bisa memuaskan pelanggan (Ningsih, 2016). Inovasi produk juga berkaitan dengan peluncuran produk, adanya produk baru merupakan salah satu bentuk dari inovasi produk. Produk baru meliputi produk orisinil, produk yang dimodifikasi, produk lama yang disempurnakan, dan merek yang dikembangkan melalui riset dan pengembangan (Pattiipeilohy, 2018).

\section{LANDASAN TEORI}

Kinerja merupakan cerminan tingkat keberhasilan suatu usaha yang dilakukan baik oleh perseorangan, kelompok, organisasi atau perusahaan. Pengertian kinerja sudah banyak didefinisikan oleh para peneliti , diantaranya Sari, (2013) mendefinisikan kinerja merupakan hasil yang telah dicapai oleh pemilik atau manajer dalam menjalankan bisnis. Kinerja pemasaran dapat diukur dengan menggunakan pertumbuhan penjualan, pertumbuhan pelanggan dan keberhasilan produk. Pada dasarnya tujuan didirikannya suatu perusahaan ataupun usaha yaitu guna mendapatkan laba yang maksimal. Oleh sebab itu diperlukan adanya kelangsungan dan peningkatan didalam kegiatan pemasaran, sedangkan yang dimaksud pemasaran adalah proses sosial terdiri dari individu maupun kelompok yang berusaha mendapatkan kebutuhan dan keinginan dengan menciptakan, menawarkan, dan mempertukarkan produk yang bernilai dengan pihak lain.

\section{Orientasi Pasar}

Orientasi pasar merupakan budaya bisnis dimana perusahaan mempunyai komitmen untuk terus berkreasi menciptakan nilai unggul bagi pelanggan (Bakti dan Harun, 2011). Perusahaan yang berorientasi pasar memiliki kemampuan lebih unggul dalam mencapai laba yang lebih tinggi dibandingkan dengan perusahaan lain yang tidak menerapkan orientasi pasar (Jaiyeoba, 2011).

\section{Modal Sosial}

Menurut Field (2010: 23) Modal Sosial adalah jumlah sumber daya, aktual ataupun maya yang terkumpul pada seorang individu maupun kelompok karena memiliki jaringan yang tahan lama, berupa hubungan timbal balik perkenalan dan pengakuan ada dua bentuk 
modal sosial, yaitu modal sosial ekslusif atau mengikat dan modal sosial inklusif atau menjembatani. Modal sosial adalah hubungan sosial, hubungan antar pelaku ekonomi dan hubungannya dengan lembaga-lembaga ekonomi. Modal sosial bersifat multidimensi dan terjadi pada individu dan tingkat organisasi yang ada pada perusahaan. Modal sosial mempunyai dua dimensi yang memiliki implikasi berbeda pada hasil yang bisa dicapai dan munculnya pengaruh proses kehidupan dan pembangunan masyarakat. Kedua dimensi modal sosial tersebut antara lain Bonding Social Capital dan Bridging Social Capital (Suriatna dan Ardianti, 2013).

\section{Inovasi Produk}

Globalisasi pasar menghadirkan tantangan bagi setiap perusahaan agar berinovasi secara berkelanjutan dalam menawarkan produk yang unik dan unggul, produk baru juga berperan penting dalam meningkatkan laba perusahaan. Inovasi adalah pengenalan dan penerapan dengan gagasan, proses, produk, dan prosedur baru pada unit yang menerapkannya, dirancang untuk memberikan keuntungan bagi individu maupun organisasi (Ancok, 2012: 34). Inovasi merupakan sebuah mekanisme perusahaan untuk beradaptasi dalam lingkungan yang dinamis, sehingga perusahaan mampu menciptakan nilai-nilai baru, ide-ide baru, menawarkan produk yang inovatif dan peningkatan kinerja layanan yang memuaskan pelanggan (Ningsih, 2016).

\section{METODE PENELITIAN}

Jenis penelitian ini menggunakan kuantitatif. Waktu penelitian dilaksanakan kurang lebih selama 6 bulan dari bulan Agustus 2018 sampai dengan bulan Januari 2019. Populasi Populasi dalam penelitian ini adalah pedagang di Pusat Grosir Solo. Teknik pengambilan sampel pada penelitian ini adalah nonprobability sampling yaitu pengambilan sampel yang tidak memberi peluang sama bagi populasi untuk dipilih menjadi sampel. Sampel penelitian ini berjumlah 100 responden. Analisis data dengan uji asumsi klasik, regresi linear berganda, uji $\mathrm{F}$, uji $\mathrm{t}$ dan koefisien determinasi $\left(\mathrm{R}^{2}\right)$.

\section{HASIL DAN PEMBAHASAN}

\subsection{Hasil}

Persamaan Regresi bertujuan untuk mengetahui seberapa besar pengaruh variabel independen Orientasi Pasar $\left(\mathrm{X}_{1}\right)$, Modal Sosial $\left(\mathrm{X}_{2}\right)$, dan Inovasi Produk $\left(\mathrm{X}_{3}\right)$ terhadap Kinerja Pemasaran (Y). Hasil dari uji regresi linear berganda dijelaskan pada tabel 1 dibawah ini

Tabel 1 : Hasil Uji Analisis Regresi Linear Berganda

\begin{tabular}{llllll}
\hline \multicolumn{1}{c}{ Variabel } & $\mathrm{B}$ & beta & $\mathrm{t}_{\text {hitung }}$ & Sig t & Ket \\
\hline (Constant) & 3,463 & & & & \\
\hline Orientasi Pasar & 0,221 &, 273 & 3,077 & 0,003 & Signifikan \\
\hline Modal Sosial & 0,183 &, 224 & 2,641 & 0,010 & Signifikan \\
\hline Inovasi Produk & 0,364 &, 411 & 4,198 & 0,000 & Signifikan \\
\hline
\end{tabular}




\begin{tabular}{ccc}
\hline F hitung & 62,617 & \\
\hline Sig F & 0.000 & \\
\hline R square & 0,651 & \\
\hline Variabel Dependent & & Kinerja Pemasaran \\
\hline
\end{tabular}

Berdasarkan hasil analisis regresi linier berganda diperoleh persamaan garis regresinya sebagai berikut:

$$
\mathbf{Y}=3,463+0,221 \mathbf{X}_{1}+0,183 \mathbf{X}_{\mathbf{2}}+0,364 \mathbf{X}_{\mathbf{3}}
$$

Keterangan :

a. Diperoleh nilai konstanta 3,463 artinya variabel dependen kinerja pemasaran dipengaruhi oleh variabel orientasi pasar, modal sosial dan inovasi produk sehingga mempunyai pengaruh positif sebesar 3,463.

b. Koefesien Orientasi Pasar memberikan nilai positif yang artinya jika Orientasi Pasar semakin baik dengan asumsi variabel tetap maka kinerja pemasaran akan mengalami peningkatan sebesar 0,221 .

c. Koefisien modal sosial memberikan nilai positif artinya bahwa jika modal sosial semakin kuat dengan asumsi variabel lain tetap maka kinerja pemasaran akan mengalami peningkatan sebesar 0,183 .

d. Koefisien Inovasi Produk memberikan nilai positif yang artinya jika perusahaan membuat produk yang sesuai dengan kebutuhan masyarakat dengan asumsi variabel lain tetap maka keputusan pembelian akan mengalami peningkatan sebesar 0,364

\section{Uji Hipotesis}

a. Pengujian ini digunakan untuk mengetahui signifikan pengaruh variabel Orientasi pasar $\left(\mathrm{X}_{1}\right)$, Modal sosial $\left(\mathrm{X}_{2}\right)$ dan Inovasi Produk $\left(\mathrm{X}_{3}\right)$ secara bersama-sama terhadap kinerja pemasaran (Y). Hasil uji $\mathrm{F}$ pada Tabel 1 diketahui besarnya nilai $\mathrm{f}$ hitung $\geq \mathrm{f}_{\text {tabel }}(62,617) \geq$ $(2,70)$ dengan signifikan $0,000 \leq 0,05$ maka dapat disimpulkan $\mathrm{H}_{\mathrm{O}}$ ditolak artinya variabel Orientasi pasar, modal sosial dan inovasi produk secara simultan dan signifikan berpengaruh terhadap kinerja pemasaran pedagang Di Pusat Grosir Solo.

b. Uji t

Uji t digunakan untuk menguji signifikan secara parsial pengaruh variabel independen yang terdiri dari Orientasi pasar $\left(\mathrm{X}_{1}\right)$, modal sosial $\left(\mathrm{X}_{2}\right)$ dan Inovasi produk $\left(\mathrm{X}_{3}\right)$ terhadap variabel dependen yaitu kinerja pemasaran $(\mathrm{Y})$. Berdasarkan hasil analisis penelitian pada tabel 1dapat diambil kesimpulan sebagai berikut

1) Pada variabel orientasi pasar hasil nilai $t$ hitung $(3,077) \geq t$ tabel $(1,984)$ dengan signifikan $0,003 \leq 0.05$ artinya $\mathrm{H}_{0}$ ditolak, secara parsial orietasi pasar memiliki pengaruh positif dan signifikan terhadap kinerja pemasaran pedagang di Pusat Grosir Solo.

2) Pada variabel modal sosial $\left(X_{2}\right)$ hasil nilai $t$ hitung $(2,641) \geq t_{\text {tabel }}(1,984)$ dengan signifikan $0,010 \leq 0.05$ artinya $\mathrm{H}_{0}$ ditolak, secara parsial kualitas produk $\left(\mathrm{X}_{2}\right)$ memiliki pengaruh positif dan signifikan terhadap kinerja pemasaran pedagang di Pusat Grosir Solo 
3) Pada variabel inovasi produk $\left(\mathrm{X}_{3}\right)$ hasil nilai $\mathrm{t}$ hitung $(4,198) \geq \mathrm{t}$ tabel $(1,984)$ dengan signifikan $0,000 \leq 0.05$ artinya $\mathrm{H}_{0}$ ditolak, secara parsial inoasi produk $\left(\mathrm{X}_{3}\right)$ memiliki pengaruh positif dan signifikan terhadap kinerja pemasaran pedagang di Pusat Grosir Solo

\section{c. Koefisien Determinasi $\left(\mathrm{R}^{2}\right)$}

Koefisien determinasi pada intinya untuk mengukur seberapa jauh variabel bebas dalam menerangkan variabel terikat. Hasil dari perhitungan analisis regresi linear berganda dapat diketahui bahwa besarnya koefisien detrminasi (AdjustedR ${ }^{2}$ )yang diperoleh 0,651 atau $65,1 \%$. Hal ini menunjukkan bahwa 65,1\% kinerja pemasaran pedagang di Pusat Grosir Solo dipengaruhi oleh variabel independen berupa variabel orientasi pasar, variabel modal sosial dan variabel inovasi produk Sedangkan sisanya sebesar 34,9\% dipengaruhi oleh variabel lain diluar dari variabel penelitian.

\subsection{Pembahasan}

a. Hasil penelitian menunjukkan variabel orientasi pasar $\left(\mathrm{X}_{1}\right)$ diperoleh nilai $\mathrm{t}_{\text {hitung }} 3,077$ dengan nilai signifikan ,003 dan koefisien regresi mempunyai nilai positif sebesar 0,221 berdasarkan hasil tersebut diperoleh keterangan bahwa variabel orientasi pasar berpengaruh positif terhadap kinerja pemasaran pedagang di Pusat Grosir Solo secara signifikan. Hal ini dikarenakan Perusahaan yang berorientasi pasar memiliki kemampuan lebih unggul dalam mencapai laba yang lebih tinggi dibandingkan perusahaan yang tidak menerapkan orientasi pasar. Penelitian ini mendukung penelitian yang dilakukan oleh Adijati Utaminingsih (2016) menyatakan bahwa Orientasi Pasar berpengaruh secara positif dan signifikan terhadap kinerja pemasaran.

b. Hasil penelitian menunjukkan variabel modal sosial $\left(\mathrm{X}_{2}\right)$ diperoleh nilai $\mathrm{t}$ hitung 2,641 dengan nilai signifikan ,010 dan koefisien regresi mempunyai nilai positif sebesar 0,183 berdasarkan hasil tersebut diperoleh keterangan bahwa variabel modal sosial berpengaruh positif terhadap kinerja pemasaran pedagang di Pusat Grosir Solo secara signifikan. Modal sosial sangat penting dalam pembentukan modal manusia, hal ini sering digunakan untuk meningkatkan tingkat pendidikan yang lebih baik untuk para pedagang di Pusat Grosir Solo agar para pedagang memahami pentingnya hubungan baik antar sesama pedagang. Jika modal sosial rendah maka akan menyebabkan konflik dan tingkat kepercayaan rendah, itu berarti pentingnya partisipasi dalam hubungan sosial antar pedagang untuk menghasilkan sumber daya manusia yang lebih baik. Penelitian ini sejalan dengan penelitian yang dilakukan Sugiyanto dan Marka (2017) yang menyatakan Modal Sosial memiliki pengaruh positif dan signifikan terhadap kinerja pemasaran

c. Hasil penelitian menunjukkan variabel inovasi produk $\left(\mathrm{X}_{3}\right)$ diperoleh nilai t hitung 4,198 dengan nilai signifikan 0,000 dan koefisien regresi mempunyai nilai positif sebesar 0,364 berdasarkan hasil tersebut diperoleh keterangan bahwa variabel inovasi produk berpengaruh positif terhadap kinerja pemasaran pedagang di Pusat Grosir Solo secara signifikan. Inovasi produk merupakan salah satu faktor persaingan yang paling penting untuk mencapai kesuksesan dimana akhir-akhir ini lingkungan bisnis berubah dengan cepat. Inovasi merupakan sebuah mekanisme perusahaan untuk beradaptasi dalam lingkungan yang dinamis, sehingga perusahaan mampu menciptakan nilai-nilai baru, ide-ide baru, menawarkan produk yang inovatif dan peningkatan kinerja layanan yang memuaskan pelanggan. Penelitian ini sejalan dengan penelitian Sarjita (2017) menyatakan inovasi produk ada pengaruh positif dan signifikan terhadap kinerja pemasaran. 
d. Hasil penelitian ini diperoleh peneliti bahwa variabel orientasi pasar, modal sosil dan inovasi produk berpengaruh secara simultan dan signifikan terhadap kinerja pemasaran pedagang di Pusat Grosir Solo . Pernyataan tersebut berdasarkan hasil perhitungan uji F, dengan membandingkan $F_{\text {hitung }}$ dan $F_{\text {tabel }}$ dimana $F_{\text {hitung }}(62,617) \geq F_{\text {tabel }}(2,70)$, dan nilai signifikasi adalah $0,000 \leq 0,05$. Kinerja pemasaran merupakan ukuran prestasi yang diperoleh dari proses pemasaran secara menyeluruh dari sebuah perusahaan. Kinerja pemasaran juga dapat dipandang sebagai sebuah konsep yang digunakan untuk mengukur sampai sejauh mana prestasi pasar yang telah dicapai oleh suatu produk yang dihasilkan perusahaan. Variabel yang sering digunakan untuk mengukur dampak strategi pemasaran dan orientasi pasar yang ditetapkan perusahaan adalah kinerja pemasaran Penelitian ini bermaksud untuk menganalisis pengaruh Orientasi Pasar, Modal Sosial dan Inovasi Produk terhadap kinerja pemasaran.

\section{KESIMPULAN DAN SARAN}

\subsection{Kesimpulan}

Kesimpulan dari penelitian Orientasi pasar, Modal Sosial dan Inovasi Produk terhadap kinerja pemasaran pedagang di Pusat Grosir Solo adalah sebagai berikut:

1. Hasil uji $\mathrm{F}$ menunjukan bahwa variabel Orientasi Pasar, Modal Sosial dan Inovasi Produk secara simultan dan signifikan memberikan pengaruh yang positif terhadap kinerja pemasaran.

2. Orientasi pasar berpengaruh positif dan signifikan terhadap kinerja pemasaran pedagang di Pusat Grosir Solo.

3. Modal sosial berpengaruh positif dan signifikan terhadap kinerja pemasaran pedagang di Pusat Grosir Solo

4. Inovasi produk berpengaruh positif dan signifikan terhadap kinerja pemasaran pedagang di Pusat Grosir Solo.

5. Hasil analisis koefisien determinasi diperoleh nilai sebesar 0,651. Yang berarti kinerja pemasaran pedagang di Pusat Grosir Solo dipengaruhi oleh variabel independen berupa variabel orientasi pasar, variabel modal sosial dan variabel inovasi produk sebesar $65,1 \%$. Sedangkan sisanya sebesar $34,9 \%$ dipengaruhi oleh variabel lain diluar dari variabel penelitian

\subsection{Saran}

Berdasarkan simpulan dan Pembahasan hasil penelitian, maka saran yang dapat dijadikan pertimbangan adalah sebagai berikut:

1. Seharusnya perusahaan harus mempertahankan, meningkatkan kualitas Orientasi pasar dan Modal Sosial yang telah dilakukan agar dimasa depan kinerja pemasaran pedagang di Pusat Grosir Solo lebih meningkat, juga memperluas pangsa pasar serta meningkatkan laba perusahaan

2. Sebaiknya perusahaan meningkatkan dan membuat ide-ide baru dengan Inovasi produk agar masyarakat lebih tertarik untuk membeli produk yang ada di Pusat Grosir Solo. 


\section{DAFTAR PUSTAKA}

Bakti, Sukma dan Harun, Harniza. 2011. Pengaruh Orientasi Pasar Dan Nilai Pelanggan Terhadap Kinerja Pemasaran Masakapai Penerbangan Lion Air. Jurnal Pemasaran Modern. Vol. 3.No. 3

Utaminingsih, Adijati. 2016. Pengaruh Orientasi Pasar, Inovasi Dan Kreativitas Strategi Pemasaran Terhadap Kinerja Pemasaran Pada UKM Kerajinan Rotan Di Desa Teluk Wetan, Welahan, Jepara. Media Ekonomi Dan Manajemen. Vol. 31. No. 2.

Warmana, Oka G dan Widnyana, Wayan, 2018. Pengaruh Modal Social Terhadap Kinerja Usaha Pada UD Udiana Desa Celuk, Gianyar, Bali. Jurnal Manajemen. Vol. 13. No. 1

Wirawan, Reka Yahya. 2017. Pengaruh Orientasi Pasar, Orientasi Kewirausahaan Terhadap Kinerja Pemasaran UMKM Batik Di Kabupaten Jombang. Jurnal Equilibrium. Vol. 5. No. 1. 